\title{
Anna Skórska
}

University of Economics in Katowice

e-mail: anna.skorska@ue.katowice.pl

\section{EMPLOYMENT OR UNDEREMPLOYMENT IN THE CONTEXT OF "EUROPE 2020" STRATEGY IMPLEMENTATION}

\section{ZATRUDNIENIE CZY ZATRUDNIENIE NIEADEKWATNE W KONTEKŚCIE REALIZACJI STRATEGII ,EUROPA 2020"}

DOI: $10.15611 / \mathrm{e} 21.2015 .4 .03$

Summary: In formulated long-term strategy "Europe 2020" attention is focussed on problems in the sphere of employment. Therefore one of the objectives of the strategy is to reach the employment rate on the level of $75 \%$ for women and men aged 20 to 64 by 2020 . In National Reform Programs, individual EU member states adjusted their employment objectives to local needs while considering situations on their labour markets and practical probability of changes. Due to differences in social and economic situation in EU-28, and consequences of economic crisis particularly noticeable in individual countries, these objectives are diversified. Achieving the high level of this indicator does not reflect the full situation on the labour market because of rising unemployment and underemployment. Underemployment in the form of over-education, under-qualification or involuntary part-time jobs refers to a growing number of social group, particularly women and young people. The questions that naturally arise from these considerations apply not only to the employment rates, but also to the scale of labour underutilisation, the consequences of this phenomenon for the economy, society, both on micro and macro level. The main research questions are: "What is the scale and dynamics of employment and underemployment in the European Union?", "How big are disparities across UE?", "Is there a relationship between high employment and low underemployment?", "What are the chances to achieve employment objectives in 2020?" Considering the aforementioned conditions, the goal of the paper is to present a diversity in employment and underemployment rate in EU-28 between 2008 and 2014 and to assess a potential probability of achievement of employment objectives by individual member states in the perspective of 2020. The execution of the goal formulated in this way imposed the structure of the paper that includes: 1) definition of underemployment, 2) review of employment objective in "Europe 2020" strategy, 3) analysis of the changes of employment and underemployment in EU-28 between 2000 and 2014, 4) presentation of employment objectives formulated in National Reform programs, and the assessment of their implementation.

Keywords: employment, underemployment, employment rate, "Europe 2020” strategy. 
Streszczenie: W sformułowanej długofalowej Strategii „Europa 2020” zwraca się uwagę na problemy w obszarze zatrudnienia. Stąd jednym z celów strategii jest osiągnięcie do 2020 roku 75\% wskaźnika zatrudnienia dla kobiet i mężczyzn w wieku 20-64 lata. Poszczególne kraje członkowskie UE w Krajowych Programach Reform, po uwzględnieniu sytuacji na ich rynkach pracy oraz realnych możliwości zmian, dopasowały swoje cele zatrudnieniowe do lokalnych potrzeb. Ze względu na zróżnicowanie sytuacji społeczno-gospodarczej w UE-28, a szczególnie odczuwalnych w poszczególnych krajach skutków kryzysu gospodarczego, cele te są zróżnicowane. Osiągnięcie wysokiego wskaźnika zatrudnienia nie w pełni odzwierciedla rzeczywistą sytuację na rynku pracy, na co wskazuje rosnący poziom bezrobocia oraz zatrudnienia nieadekwatnego. Zatrudnienie niezgodne z kwalifikacjami, wykształceniem, czy poniżej oczekiwanego czasu pracy dotyczy rosnącej liczby osób, a szczególnie kobiet i młodych ludzi. Pytania, które nasuwają się w związku z powyższym, dotyczą nie tylko oczekiwanego wskaźnika zatrudnienia, ale także skali zatrudnienia nieadekwatnego oraz konsekwencji tego zjawiska, zarówno ekonomicznych, jak i społecznych, odczuwanych przez jednostkę, ale także w skali makro. Stąd główne pytania badawcze w niniejszym artykule brzmią następująco: jaka jest skala i dynamika zatrudnienia i zatrudnienia nieadekwatnego w UE, jak duże jest zróżnicowanie pomiędzy krajami członkowskimi, czy wysokiemu poziomowi zatrudnienia towarzyszy niski poziom underemployment, jakie są szanse na osiągnięcie celu zatrudnieniowego w roku 2020. Celem artykułu jest przedstawienie zróżnicowania wskaźnika zatrudnienia oraz udziału zatrudnionych nieadekwatnie wśród ogółu pracujących w UE-28 w latach 2008-2014 oraz ocena możliwości osiągnięcia celu zatrudnieniowego przez poszczególne kraje członkowskie w perspektywie roku 2020. Realizacji tak sformułowanego celu podporządkowano układ opracowania, na który składa się 1) zdefiniowanie pojęcia underemployment, 2) omówienie celu zatrudnieniowego w Strategii „Europa 2020”, 3) analiza dynamiki zatrudnienia oraz zatrudnienia nieadekwatnego w krajach UE-28 w latach 2000-2014, 4) przedstawienie celów zatrudnieniowych sformułowanych w Krajowych programach Reform oraz ocena poziomu ich realizacji.

Słowa kluczowe: zatrudnienie, zatrudnienie nieadekwatne, wskaźnik zatrudnienia, strategia „Europa 2020”.

\section{Introduction}

Searching for the method of effective use of available labour resources both in the micro and macro scale is one of major challenges in the 21 st century. It gained special importance in the face of economic crisis the beginning of which is perceived in the United States in 2006. As a result of the functioning of mechanism of transmission, its results are still observed, among others, in labour markets in various world regions, including the countries of the European Union. The decline in employment, growth in unemployment and change in its structure particularly after 2008 are symptoms of economic recessions. Coming out of economic crisis is accompanied by actions focussed on the execution of objectives included in the strategic document "Europe 2020". Strengthening the strategy of smart and sustained economic growth favouring social inclusion ought to be the European Union response to challenges of the 21 st century, both in economic and social dimension. 
The analysis of changes in employment level and rate in the countries of the European Union between 2000 and 2014 is the starting point for discussions conducted in the paper. The employment rate is a well known measure of labour utilisation, but it may give a falsely optimistic picture of the labour market and the economy. It is because an important group of people is excluded from official statistics. They are defined as underemployed - employees who are willing and available to work "better" or "more adequately". Underemployment in form of overeducation, under-qualification or involuntary part-time jobs refers to a growing number of workers, particularly women and young people.

The questions that naturally arise from these considerations apply not only to the employment rates, but also to the scale of labour underutilisation, the consequences of this phenomenon for the economy, society, both on micro and macro level. The main research questions are: "What is the scale and dynamics of employment and underemployment in the European Union"? "How big are disparities across UE?", "Is there a relationship between high employment and low underemployment?", "What are the chances to achieve employment objectives in 2020"? That is why, the goal of the paper is to present diversity in employment and underemployment rates in EU-28 between 2008 and 2014 and to assess the potential probability of achievement of employment objectives by individual member states in the perspective of 2020 .

\section{Employment or underemployment - theoretical aspects}

Employment is essential in order to guarantee a decent standard of living, but it also fulfills many other functions. It enables people to achieve their personal goals and expectations and thus is a strong factor of life satisfaction. That is why, not only the quantity, but also the quality of employment is so important. If employment does not fulfill specified standards e.g. salaries, time of work, experience and qualification level, it leads to many negative consequences. This phenomenon is called underemployment and is one of the forms of labour underutilization - see Figure 1. Hence, the employment analysis should include underemployment rates.

It ought to be stressed that there are many different definitions of underemployment in literature (e.g. [International Labour Organization 1998], Australian Bureau of Statistics (ALS) [Wilkins 2004], US Bureau of Labor Statistics (BLS) [Alternative Measures...], Eurostat and many others) what causes some problems, especially in comparative research. Because underemployment means different things to different people, the definition of underemployment in any study must be explicitly stated to enable proper understanding and use of its results.

Underemployment may take a number of different forms; most prevailing of them are:

- underutilization of skills, which occurs when workers with higher level of education and/or job experience are employed in occupations that do not require 
such qualifications. It also may appear when individuals are employed in a field outside of their area of formal education or expertise whether or not the level of educational attainment is a good match to employment requirements,

- income-related underemployment exists when a worker's income is lower than it would otherwise be because of some feature of the employer or workplace, like inadequate equipment, insufficient training, or poorly organized working arrangements,

- labour hoarding occurs when a firm does not utilize all of the labor that it pays for,

- excessive working hours are the flip side of time-related underemployment. Both are forms of mismatch between hours preferred and hours worked, and both can have similar sorts of adverse consequences,

- time-related underemployment occurs when workers are willing and able to supply their labour full-time, but work in part-time jobs as they could not find full-time employment.

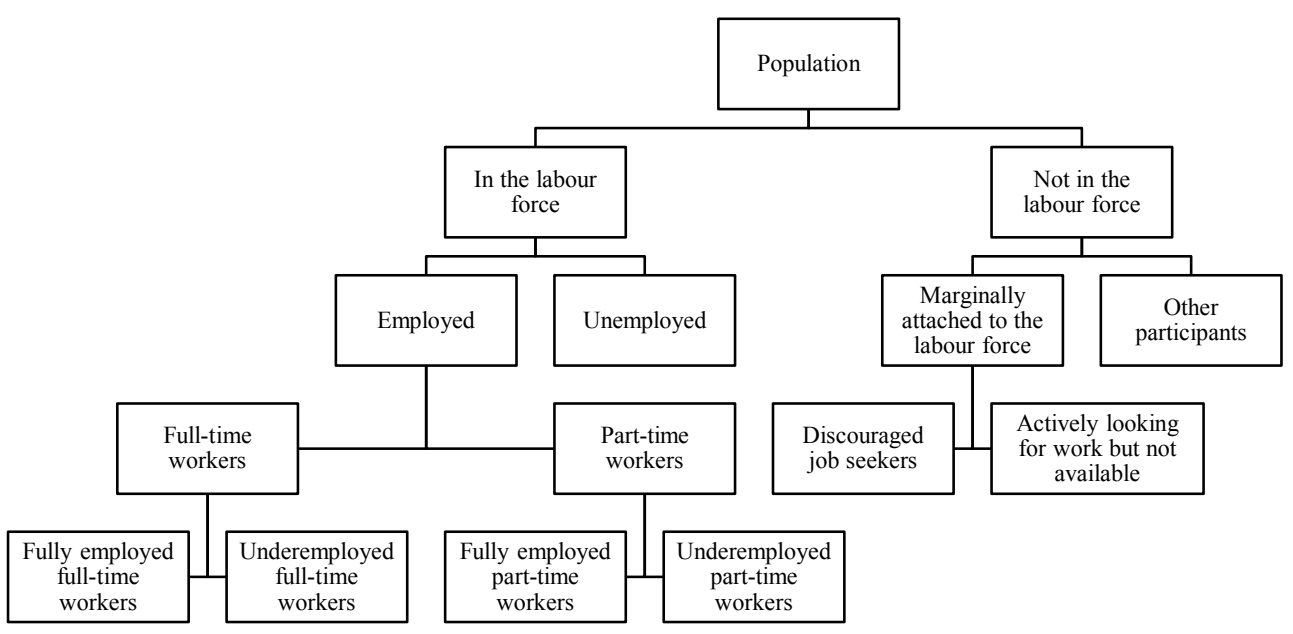

Figure 1. Labour supply framework

Source: own study.

The first form of underemployment is often called "an invisible underemployment" because the data collection tools currently do not gather information on the degree of matching between the level of individual's skills and the requirements of the job they perform. In turn, underutilization of labour is often called a "visible underemployment" as a number of indicators exist to capture this phenomenon [International Labour Organization 1998], and this form of underemployment is the subject of the paper.

According to the ILO definition, persons in time-related underemployment comprise all persons in employment who satisfy the following three criteria during the reference period used to define employment - see Figure 2: 
1) willing to work additional hours, i.e. wanted another job (or jobs) in addition to their current job (or jobs) to increase their total hours of work; to replace any of their current jobs with another job (or jobs) with increased hours of work; to increase the hours of work in any of their current jobs; or a combination of the above;

2) available to work additional hours, i.e. are ready, within a specified subsequent period, to work additional hours;

3) worked less than a threshold relating to working time, i.e. persons whose hours actually worked in all jobs in the reference period, were below a threshold, to be chosen according to "national circumstances".

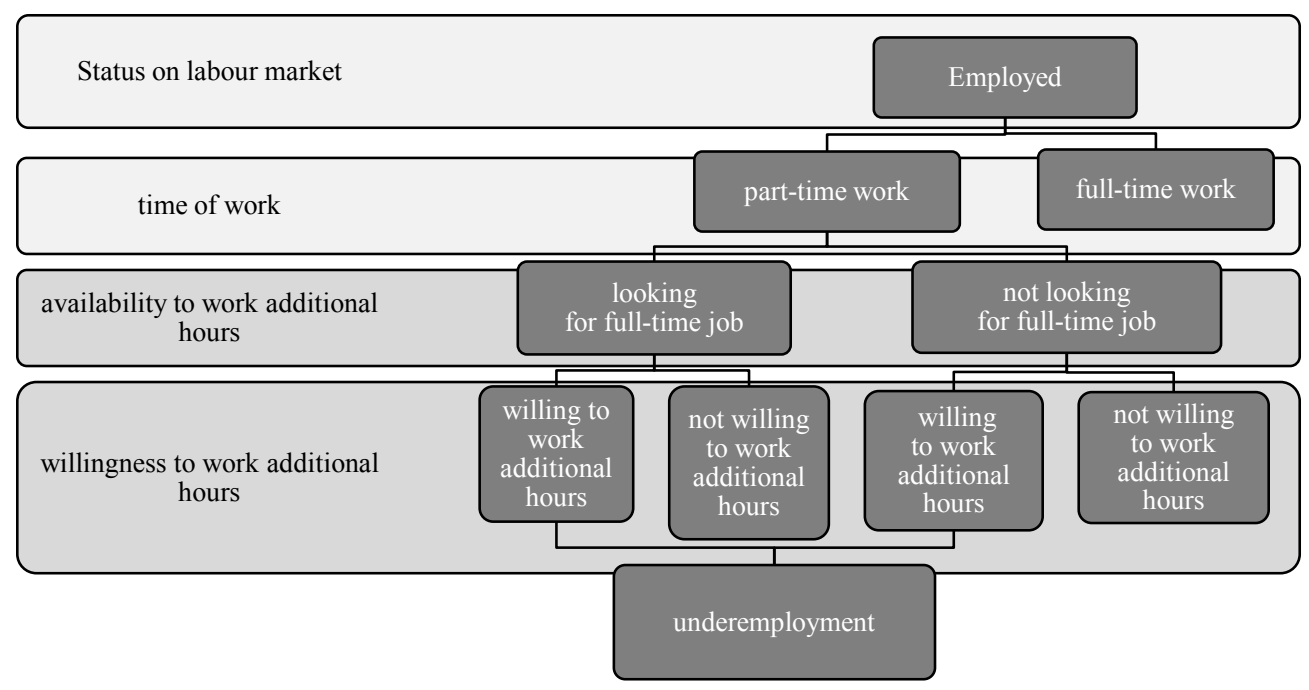

Figure 2. Underemployment - MOP definition

Source: own study based on [International Labour Organization 1998].

Reflecting the view that time-related underemployment is essentially a problem of part-time employment, one particular type of time-related underemployment for which data are commonly collected is involuntary part-time employment.

\section{3. "Europe 2020" strategy - employment objective}

"Europe 2020" strategy [Strategy for smart... 2010] is another ten-year strategy of the European Union for economic growth and employment, started in 2010 after Lisbon Strategy had been completed. Its objective is to achieve economic growth that shall be:

- smart - thanks to more effective investments in education, scientific research and innovations;

- $\quad$ sustained - thanks to a definite shift towards low-emission economy; 
- favouring social inclusion with particular emphasis on the creation of new workplaces and limiting the poverty.

The strategy focuses on five, far-reaching objectives in the field of employment, innovativeness, education and struggle with poverty as well as in the sphere of climate and energy. Some of them, just like in Lisbon Strategy, are rather based on wishful thinking than a reality-based approach.

The objective formulated in the area of employment is ambitious, however, there arises a question if it is possible to attain. In quantitative approach, it is assumed that in the perspective of 2020 the employment rate for women and men aged 20-64 will reach 75\%. In contrast to assumptions of the Lisbon Strategy the rate of employment for women and men ought to be the same, which can bring some concerns about its possible negative impact on the level of fertility. Age adjustment, from the current age of 15-64 to 20-64, for which the employment rate is calculated, also ought to be taken into consideration as it automatically increases the employment rate. Additionally, in adopted National Reform Programs that are fundamental instruments of the Strategy implementation, each member state assumed the objective in the sphere of employment that was adequate to local possibilities. Flagship initiatives of member states, regional and local governments, developed by the European Commission and realised on the level of EU offer support for their implementation.

In the "Program for new skills and jobs" [Program for new... 2010] the following priorities were adopted:

1. Labour markets functioning better on the basis of the model of flexible labour market and social security (flexicurity) that ought to be re-analysed and readjusted to post-crisis situation, reduction in segmentation of labour market or support for gender equality.

2. Labour force better qualified thanks to investing in systems of education and training and also predicting the needs in the sphere of skills and services with respect to adjustment and counselling.

3. Higher quality of workplaces and better working conditions. High quality of workplaces in EU is related to equally high labour efficiency and share in the employment.

4. More effective policy stimulating the creation of workplaces and demand on work. Selective reductions in non-salary labour costs or appropriately oriented directions in employment can be a factor encouraging employers to recruit people who are unemployed for a long time and other workers who leave the labour market. The policy enabling the exploitation of major sources of new workplaces and promoting entrepreneurship and self-employment are also important for the increase in employment rates.

To increase probability of their implementation, 13 key activities have been suggested. They need diversified EU instruments of policy, including legislation, policy coordination, social dialogue, financing and strategic partnerships. EU 
initiatives addressed at particular groups of risk, including "Mobile youth" or strategy for men and women equality constitute the complementation of the program (2010$-2015)$.

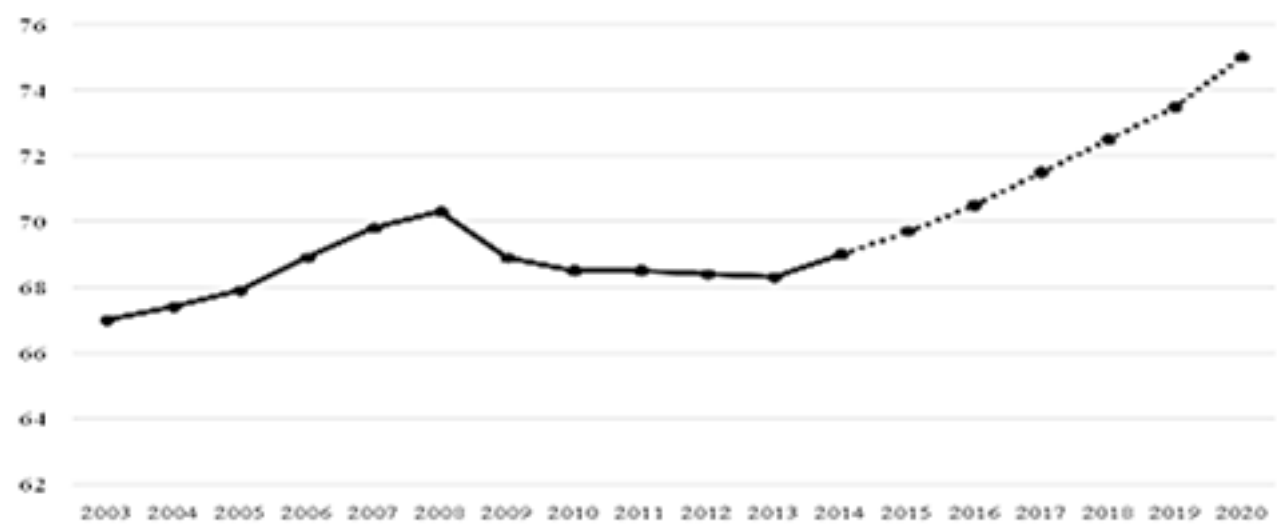

Figure 3. Employment rate in EU-28 in 2002-2013 and employment rate target in 2020 - \%

Source: [http://ec.europa.eu/europe2020/pdf/themes/19_employment_rate_target_02.pdf].

The analysis of accessible data shows that between 2002 and 2008 the growth by 3.6 percentage point, exceeding the level of $70 \%$ in 2008 was observed. In subsequent years a gradual decrease of this rate was observed as one of results of economic crisis in the whole EU. In 2014 employment rate in EU was 68.4\% - see Figure 3. This means that the achievement of the assumed objective by 2020 will require the increase in employment by over 6 percentage point. At current pace of employment growth the achievement of the objective seems little possible. A particularly significant gap in this area is observed in the case of women's employment (62.5\% in comparison with $74.2 \%$ of men in 2014) and elderly people aged 55-64 (50.2\% in 2014).

Apart from the obligation to reach $75 \%$ employment rate in the whole EU, in 2011 each member state determined its own employment objective. They are different, from $62.9 \%$ in Croatia, $71 \%$ in Poland to $80 \%$ in Denmark, Holland or Sweden [http://ec.europa.eu/europe2020/pdf/targets_pl.pdf]. Considering the level of employment rate, EU can be divided into 4 groups:

- countries of the lowest employment rate in 2014 (below 60\%) - Greece, Spain, Croatia, Italy,

- countries of medium-low employment level(60-69\%) - Belgium, Ireland, Cyprus, Hungary, Malta, Poland, Portugal, Romania, Slovenia, Slovakia, Bulgaria,

- countries of medium employment level (69-75\%) - Czech Republic, Estonia, Finland, Luxembourg, Lithuania, Latvia, France,

- countries of high employment (over 75\%) - Denmark, Germany, Holland, Austria, Sweden and Great Britain. 
The choice of national objectives has significant implications for the attainment of EU objective. This is because if all EU members achieve or exceed their objectives in 2020 , achievement of $74 \%$ employment share shall be real for the whole Union.

\section{Changes in employment in EU-28 between 2000 and 2014}

Fluctuations in the economic situation are one of the features typical of market economies. The period of growth is preceded by the economy slowdown or breakdown. The history of the 20th and the 21 st century economy confirms that consequences of almost every economic crisis found their reflections on the labour market. In the period of good economic situation, until 2008, an increase in employment and a decrease in unemployment were observed in almost all European Union member states, while the pace of changes was diversified [Skórska 2012]. Between 2000 and 2008 the largest increase in employment was observed in Bulgaria (15 percentage points) and in Latvia (by 12\%), whereas the lowest was observed in Luxembourg and in Hungary (slightly over 1 percentage point). The only countries that reported a decline in employment in the analysed period were Romania and Portugal - see Table 1. At the same time, diversity in the level of employment in particular EU countries and occurring differences in this sphere should be stressed. While the mean level of use of available labour resources in EU-28 is between 66$68 \%$, in Croatia and Malta it is lower by 6-8 percentage points, whereas in Holland, Sweden and Denmark it is higher by $8-10$ percentage points - see Table 1. Poland belongs to the group of countries of relatively low employment rate, although in contrast to many European countries, its dynamic growth is observed. Only between 2004 and 2008 this rate grew there by 8 percentage points.

Global economic crisis, the beginning of which is perceived in the breakdown of financial sector in the United States in 2007, had an impact of diversified intensity on social and economic situation of individual countries, including their labour markets. Thanks to the lower development level of institutions of financial and banking sector, smaller openness of economy and more efficient monetary policy, Poland experienced consequences of the crisis with smaller intensity than other European Union member states. However, it does not mean that the rate of economic growth or the dynamics of employment increase were not slowed down because of that or that consequences of increase in unemployment were not experienced by the population. Between 2008 and 2010 employment declined by nearly 330 thousand, and considering the fact that between 2005 and 2008 the growth of workplaces was higher than 1.68 million, it was a significant change. The impact of global financial crisis on the real sphere of economy was manifested in, among others, serious reduction of purchases made by consumers. It was additionally intensified by limitations in the access to consumer credits, remarkable deterioration of moods of business entities resulting from difficulties in the access to credits and raising their costs as well as limitation in investment expenditures, reduction in production and breakdown in many trades, 
Table 1. Employment (20-64) in European Union states between 2000 and 2014

\begin{tabular}{|c|c|c|c|c|c|c|c|c|c|c|c|c|c|c|}
\hline \multirow{3}{*}{ Country } & \multicolumn{4}{|c|}{ Employment } & \multicolumn{2}{|c|}{ Change } & \multicolumn{2}{|c|}{ Employment } & \multicolumn{2}{|c|}{ Change } & \multicolumn{2}{|c|}{ Employment } & \multicolumn{2}{|c|}{ Change } \\
\hline & $\mathrm{mln}$ & $\%$ & $\mathrm{mln}$ & $\%$ & thou & $\%$ & $\mathrm{mln}$ & $\%$ & thou & $\%$ & $\mathrm{mln}$ & $\%$ & thou & $\%$ \\
\hline & \multicolumn{2}{|c|}{2000} & \multicolumn{2}{|c|}{2004} & \multicolumn{2}{|c|}{$2000-2004$} & \multicolumn{2}{|c|}{2008} & \multicolumn{2}{|c|}{$2004-2008$} & \multicolumn{2}{|c|}{2014} & \multicolumn{2}{|c|}{$2008-2014$} \\
\hline EU-28 & : & $:$ & 199.6 & 67.2 & $:$ & : & 213.3 & 70.3 & 13972.4 & 107.0 & 208.9 & 68.4 & -4374.9 & 97.9 \\
\hline Belgium & 4.1 & 66.3 & 4.1 & 65.8 & 38.7 & 100.9 & 4.4 & 68 & 280.9 & 106.8 & 4.5 & 67.2 & 99.4 & 102.2 \\
\hline Bulgaria & 2.8 & 56.5 & 2.9 & 61.2 & 98.5 & 103.5 & 3.3 & 70.7 & 374.2 & 112.8 & 2.9 & 63.5 & -359.4 & 89.0 \\
\hline Czech Rep. & 4.5 & 70.9 & 4.6 & 70.1 & 37.9 & 100.8 & 4.9 & 72.4 & 296.4 & 106.4 & 4.8 & 72.5 & -35.9 & 99.2 \\
\hline Denmark & 2.5 & 77.9 & 2.5 & 78.1 & 11.7 & 100.4 & 2.6 & 79.7 & 70.1 & 102.7 & 2.5 & 75.6 & -124.7 & 95.2 \\
\hline Germany & 34.6 & 68.7 & 33.8 & 67.9 & -760.4 & 97.8 & 36.6 & 74 & 2717.7 & 108.0 & 37.8 & 77.1 & 1297.2 & 103.5 \\
\hline Estonia & 0.62 & 67.5 & 0.57 & 70.2 & 11.4 & 102.0 & 0.62 & 77.1 & 48.3 & 108.4 & 0.59 & 73.2 & -27.9 & 95.5 \\
\hline Ireland & 1.5 & 70.1 & 1.7 & 71 & 192.2 & 112.4 & 2.0 & 72.3 & 279.1 & 116.0 & 1.8 & 65.5 & -190.6 & 90.5 \\
\hline Greece & 3.9 & 62.1 & 4.3 & 64.4 & 345.6 & 108.7 & 4.5 & 66.3 & 204.4 & 104.7 & 3.5 & 52.9 & -1018.8 & 77.2 \\
\hline Spain & 14.9 & 60.6 & 17.6 & 65.2 & 2618.4 & 117.4 & 19.9 & 68.5 & 2401.8 & 113.6 & 17.1 & 58.6 & -2856.1 & 85.7 \\
\hline France & 22.6 & 67.4 & 24.1 & 69.1 & 1416.0 & 106.2 & 25.3 & 70.4 & 1245.3 & 105.1 & 25.2 & 69.6 & -145.5 & 99.4 \\
\hline Croatia & : & $:$ & 1.5 & 59.7 & $:$ & : & 1.7 & 62.9 & 201.0 & 113.3 & 1.5 & 57.2 & -175.5 & 89.6 \\
\hline Italy & 20.3 & 57.1 & 21.8 & 61.6 & 1465.2 & 107.2 & 22.5 & 63 & 716.5 & 103.2 & 21.7 & 59.8 & -747.0 & 96.6 \\
\hline Cyprus & 0.28 & 72 & 0.32 & 75.7 & 40.7 & 114.4 & 0.36 & 76.5 & 44.0 & 113.6 & 0.35 & 67.2 & -11.6 & 96.8 \\
\hline Latvia & 0.90 & 63.4 & 0.91 & 69.3 & 8.9 & 100.9 & 0.99 & 75.4 & 84.0 & 109.2 & 0.85 & 69.7 & -140.4 & 85.8 \\
\hline Lithuania & 1.4 & 66.1 & 1.4 & 69.6 & 37.2 & 102.7 & 1.4 & 72 & -10.0 & 99.2 & 1.3 & 69.9 & -104.4 & 92.4 \\
\hline Luxembourg & 0.17 & 67.5 & 0.18 & 67.7 & 8.9 & 105.0 & 0.19 & 68.8 & 13.3 & 107.1 & 0.24 & 71.1 & 40.4 & 120.2 \\
\hline Hungary & 3.7 & 60.9 & 3.9 & 62 & 117.7 & 103.1 & 3.8 & 61.9 & -46.3 & 98.7 & 4.1 & 63.2 & 250.3 & 106.5 \\
\hline Malta & 0.13 & 57.5 & 0.13 & 57.3 & 4.9 & 103.6 & 0.15 & 59.2 & 13.3 & 109.6 & 0.17 & 64.8 & 21.1 & 113.9 \\
\hline Netherlands & 7.3 & 74.2 & 7.5 & 74.9 & 207.0 & 102.8 & 7.9 & 78.9 & 391.8 & 105.2 & 7.6 & 76.5 & -265.2 & 96.6 \\
\hline Austria & 3.5 & 70.7 & 3.5 & 69.6 & -42.8 & 98.7 & 3.7 & 75.1 & 309.7 & 109.0 & 3.8 & 75.5 & 138.6 & 103.7 \\
\hline Poland & 13.9 & 61.1 & 13.3 & 57 & -745.0 & 94.6 & 15.4 & 65 & 2153.3 & 116.2 & 15.5 & 64.9 & 108.0 & 100.7 \\
\hline Portugal & 4.5 & 73.4 & 4.6 & 72.6 & 89.7 & 101.9 & 4.7 & 73 & 66.2 & 101.4 & 4.2 & 65.4 & -494.5 & 89.5 \\
\hline Romania & 9.6 & 70.5 & 8.6 & 64.7 & -875.8 & 90.7 & 8.8 & 64.4 & 178.1 & 102.0 & 8.2 & 63.9 & -572.8 & 93.4 \\
\hline Slovenia & 0.85 & 68.6 & 0.91 & 71 & 49.8 & 105.7 & 0.95 & 73 & 47.5 & 105.2 & 0.88 & 67.2 & -74.6 & 92.1 \\
\hline Slovakia & 2.1 & 63 & 2.1 & 63.5 & 74.2 & 103.6 & 2.4 & 68.8 & 281.6 & 113.2 & 2.3 & 65 & -65.7 & 97.2 \\
\hline Finland & 2.3 & 72.3 & 2.3 & 72.5 & 28.0 & 101.2 & 2.4 & 75.8 & 129.7 & 105.6 & 2.3 & 73.3 & -100.8 & 95.8 \\
\hline Sweden & 3.9 & 76.3 & 4.1 & 77.8 & 158.2 & 103.9 & 4.3 & 80.4 & 226.5 & 105.5 & 4.5 & 79.8 & 136.2 & 103.1 \\
\hline United Kingdom & 25.3 & 73.9 & 26.2 & 74.9 & 899.0 & 103.5 & 27.5 & 75.2 & 26596.4 & 104.7 & 28.5 & 74.9 & 1045.8 & 103.8 \\
\hline
\end{tabular}

Source: own calculations based on data from Eurostat [http://eurostat.ec.europa.eu/]. 
including construction sector and automobile industry. These phenomena caused a decline in employment and an increase in unemployment contributing to further deterioration of consumer moods and limitation of purchases [Orłowski et al. 2010]. These changes were particularly intensified between 2008 and 2010 when in the whole European Union 5.5 million workplaces were lost. Here it ought to be emphasised that only in Spain over 1.8 million and in Italy 530 thousand workplaces were liquidated. The largest decline in employment between 2008 and 2014 was observed in Greece (22.8 percentage points), Spain and Latvia (14 percentage points) and also in Ireland and Bulgaria (10 percentage points) - see Table 1. Although the dynamics of changes between 2000 and 2008 in the majority of EU countries showed a positive trend, in subsequent years the situation changed. In 2009 in Latvia the decline was higher than $14 \%$, in Estonia $10 \%$ and in the next year in Latvia it was $11 \%$. Luxembourg and Germany were the only exceptions, where each year growth in employment was observed (with diversified dynamics of changes) at concurrent growth in employment rate. In the case of Luxembourg those changes were observed throughout the whole research period. Employment increase was also reported since 2010 in Sweden, Great Britain, Hungary and Malta.

Conducted analysis makes us ask the following questions: Does the high employment rate guarantee high quality of jobs? Is there a relationship between high employment and low underemployment? Or: May the high share of part-time workers influence underemployment? The attempt to answer the questions formulated in this way requires reference to the scale and dynamics of underemployment in the EU-28.

\section{Underemployment in EU-28}

Underemployment can take a number of different forms, although economists have tended to focus on time-related underemployment, which is the most reliably measured. There are two main approaches to the measurement of this phenomenon: by population (head count) or hours based (volume) estimates. The headcount measure relates to the number of people whose labour is not being fully used, whereas the volume measure provides a better picture of the total amount of potential labour inputs, or hours of work available, to the economy. Some researchers construct their index [Bell, Blanchflower 2013], which combines measures of excess capacity on the intensive (hours) and extensive (jobs) margins of the labour market. The underemployment index is expressed as a percentage ${ }^{1}$.

The number of underemployed part-time workers in the whole EU-28 in 2014 exceeded $9.8 \mathrm{mln}$, which means that the rate of underemployment was $4.5 \%$. The

${ }^{1}$ All data is derived from the European Union Labour Force Survey, where underemployed workers are defined as persons aged 15-74 working part-time who wish to work additional hours and are available to do so. Part-time work is recorded as self-reported by individuals. This definition includes in particular persons in involuntary part-time who want to have a full-time job. 
Table 2. Employment and underemployment in the European Union in 2008 and 2014

\begin{tabular}{|c|c|c|c|c|c|c|c|c|c|c|}
\hline \multirow{4}{*}{ Country } & \multicolumn{10}{|c|}{ Employment } \\
\hline & \multirow{2}{*}{$\begin{array}{l}\text { Total } \\
\text { thou }\end{array}$} & \multirow{2}{*}{$\begin{array}{c}\text { Part-time employed } \\
\text { thou } \\
\end{array}$} & \multicolumn{3}{|c|}{ Underemployed } & \multirow{2}{*}{$\begin{array}{l}\text { Total } \\
\text { thou }\end{array}$} & \multirow{2}{*}{\begin{tabular}{|c|} 
Part-time employed \\
thou \\
\end{tabular}} & \multicolumn{3}{|c|}{ Underemployed } \\
\hline & & & thou & $\begin{array}{l}\text { as } \% \text { of total } \\
\text { employment }\end{array}$ & $\begin{array}{c}\text { as } \% \text { of part-time } \\
\text { employed }\end{array}$ & & & thou & $\begin{array}{l}\text { as } \% \text { of total } \\
\text { employment }\end{array}$ & $\begin{array}{l}\text { as \% of part- } \\
\text { time employed }\end{array}$ \\
\hline & \multicolumn{5}{|c|}{2008} & \multicolumn{5}{|c|}{2014} \\
\hline EU-28 & 222386 & 40139 & 7482 & 3.4 & 24.3 & 217192 & 44124 & 9802 & 4.5 & 28.0 \\
\hline Belgium & 4437 & 1001 & 36 & 0.8 & 14.3 & 4535 & 1089 & 154 & 3.4 & 9.9 \\
\hline Bulgaria & 3353 & 76,0 & 19 & 0.6 & 45.7 & 2977 & 78 & 33 & 1.1 & 61.8 \\
\hline Denmark & 2852 & 697 & 68 & 2.4 & 12.3 & 2714 & 691 & 73 & 2.7 & 16.2 \\
\hline Germany & 38471 & 9911 & 2448 & 6.4 & 22.2 & 39742 & 10910 & 1626 & 4.1 & 13.7 \\
\hline Estonia & 656 & 47 & 5 & 0.7 & 12.9 & 625 & 59 & 7 & 1.1 & 14.5 \\
\hline Ireland & 2120 & 395 & 44 & 2.1 & 13.2 & 1905 & 445 & 127 & 6.7 & 40.2 \\
\hline Greece & 4599 & 258 & 98 & 2.1 & 42.1 & 3528 & 332 & 239 & 6.8 & 69.8 \\
\hline Spain & 20456 & 2398 & 814 & 4.0 & 35.6 & 17332 & 2752 & 1576 & 9.1 & 63.4 \\
\hline France & 25867 & 4384 & 1054 & 4.1 & 31.7 & 25749 & 4857 & 1561 & 6.1 & 40.7 \\
\hline Croatia & 1764 & 137 & 33 & 1.9 & 17.8 & 1562 & 94 & 35 & 2.2 & 22.5 \\
\hline Cyprus & 380 & 28 & 7 & 2.0 & 27.3 & 363 & 51 & 34 & 9.3 & 61.9 \\
\hline Latvia & 1054 & 70 & 23 & 2.2 & 27.1 & 884 & 65 & 26 & 3.0 & 35.0 \\
\hline Lithuania & 1425 & 96 & 17 & 1.2 & 21.5 & 1315 & 118 & 31 & 2.4 & 29.8 \\
\hline Luxembourg & 202 & 36 & 2 & 0.7 & 9.4 & 245 & 46 & 5 & 2.0 & 12.6 \\
\hline Hungary & 3848 & 180 & 6 & 0.2 & 26.1 & 4100 & 261 & 80 & 2.0 & 38.6 \\
\hline Malta & 158 & 18 & 3 & 1.9 & 15.3 & 181 & 29 & 5 & 2.5 & 14.0 \\
\hline Netherlands & 8579 & 4055 & 97 & 1.1 & 4.4 & 8296 & 4190 & 169 & 2.0 & 10.7 \\
\hline Austria & 3981 & 928 & 134 & 3.4 & 10.8 & 4097 & 1134 & 169 & 4.1 & 11.0 \\
\hline Poland & 15757 & 1312 & 256 & 1.6 & 17.0 & 15826 & 1208 & 377 & 2.4 & 29.5 \\
\hline Portugal & 5017 & 549 & 95 & 1.9 & 31.6 & 4427 & 535 & 245 & 5.5 & 40.4 \\
\hline Romania & 9369 & 926 & 215 & 2.3 & 43.3 & 8613 & 859 & 238 & 2.8 & 48.5 \\
\hline Slovenia & 991 & 86 & 13 & 1.4 & 6.3 & 909 & 98 & 26 & 2.8 & 8.9 \\
\hline Slovakia & 2432 & 64 & 18 & 0.8 & 21.9 & 2362 & 123 & 47 & 2.0 & 32.2 \\
\hline Finland & 2530 & 337 & 73 & 2.9 & 25.9 & 2447 & 377 & 90 & 3.7 & 26.6 \\
\hline Sweden & 4593 & 1221 & 214 & 4.7 & 24.9 & 4772 & 1247 & 238 & 5.0 & 27.4 \\
\hline United Kingdom & 29450 & 7390 & 1266 & 4.3 & : & 30504 & 8098 & 1813 & 5.9 & 17.6 \\
\hline
\end{tabular}

Source: Ibidem. 
proportion of underemployed part-time workers among those in employment has grown from $3.4 \%$ in 2008 to $4.5 \%$ in 2014 - see Table 2 . It can be stated that it is not a big increase, however it should be stressed that $2.3 \mathrm{mln}$ more workers became underemployed.

Among the EU Member States in 2014, underemployed part-time work is highest in Cyprus (9.3\%), Spain (9.1\% of total employment), Greece $(6.8 \%)$ and Ireland (6.7\%). The lowest rates were measured in the Czech Republic (0.7\%), Estonia and Bulgaria (1.1\%). Compared to the situation six years before, the increase was particularly high in Cyprus (+7.2 pp), Ireland (+4.6 pp), and Spain ( $+5.1 \mathrm{pp})$. Only Germany $(-2.3 \mathrm{pp})$ has less underemployed part-time workers than in 2008. In Poland, the underemployment rate was $2.4 \%$ in 2014 . However, it has grown since 2008 of 121 thousand - see Table 2.

It ought to be stressed that, among those in employment, over $44.4 \mathrm{mln}$ in 2014 were part-time workers, of which $28 \%$ were underemployed and it increased $4 \mathrm{pp}$ since 2008. In 2014, the proportion of underemployed part-time workers among total part-time workers varied significantly among Member States, with the largest shares observed in South Europe - Greece (69.8\%), Italy (64.1\%), Cyprus (61.9\%), Spain $(63.4 \%)$ and the smallest in Slovenia (8.9\%), Belgium (9.9\%), the Netherlands $(10.0 \%)$.

Labour underutilisation can significantly influence the financial, personal and social lives of both individuals and their families. It can also affect the community and the economy. The consequences of underemployment for an individual may appear through the erosion or loss of skills and abilities, reduction of current and life-long income, job dissatisfaction and emotional distress which, in turn, may lead to deteriorating health. It is not only a problem for employees, but also employers. For employers, labour underutilisation and especially underemployment of workers leads to higher personnel turnover and a growing challenge in developing and retaining human capital and corporate knowledge. It is widely acknowledged that chronic underutilization of education, skills, and human capital engenders workplace frustration and low morale, and that is why thoughtful employers must create conditions under which their employees are fully engaged in their work. In return, the company can capture greater value (higher levels of productivity and profitability) from the employees who typically demonstrate initiative, effort, and loyalty [Wilkins 2007, pp. 247-275; Ham et. al 2001, pp. 1733-1751; Friedland, Price 2003, pp. 33-45]. At macro level, underemployment reduces the potential level of the nation's wellbeing as the level of utilization of labour's skills, experience and availability to work remains at sub-optimal levels. Effective policy responses to labour underutilisation require the appreciation of its causes or sources and consequences. We should also indicate most appropriate activities directed to those groups - unemployed and underemployed.

In the context of employment and underemployment it is important to consider the chances to achieve the employment objective determined in Europe 2020 strategy 
by individual member states. The attempt to answer the questions formulated in this way requires the reference to National Reform Programs in which member states determined their employment objectives.

\section{Realisation of employment objective as determined in National Reform Programs}

Employment objectives of individual EU member states were included in National Reform Programs. Due to the diversified situation in national labour markets, assumed objectives show remarkable differences - see Figure 4.

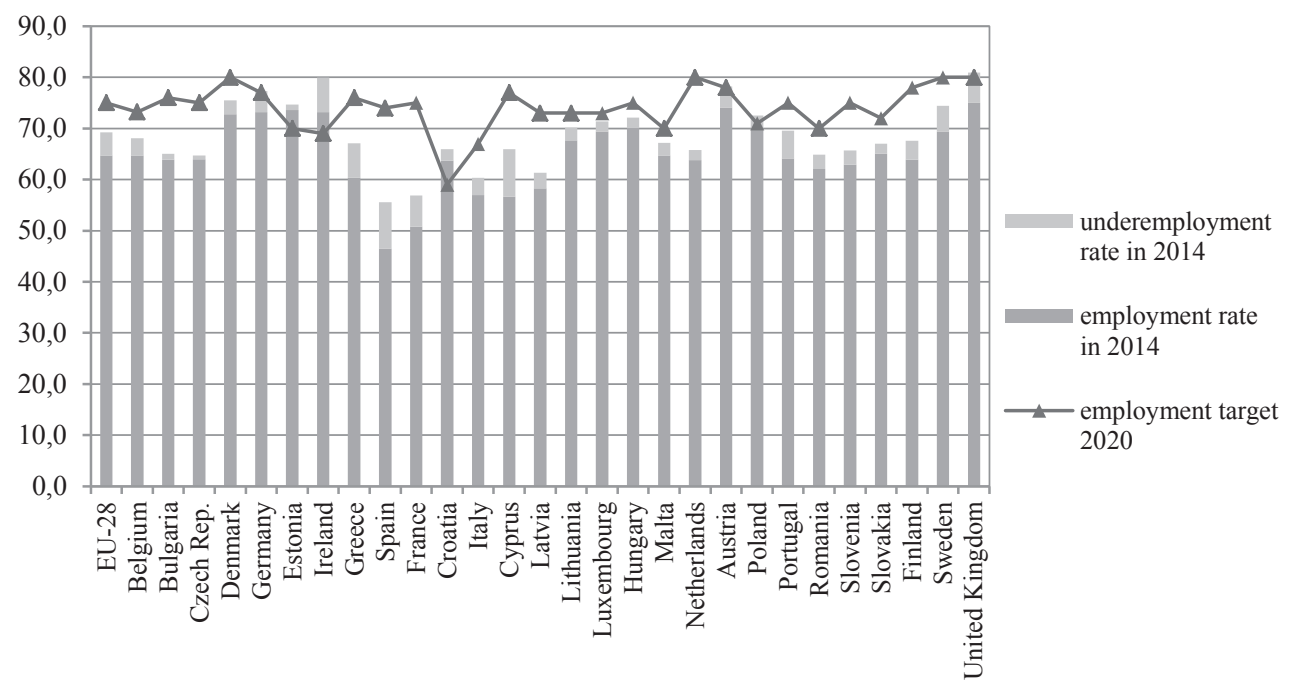

Figure 4. National employment rate targets in 2020, employment and underemployment rates in $2014-\%$ Source: own calculations.

The analysis of existing data shows deep disproportions among EU countries both with reference to the situation in the labour market and to real possibilities of achievement of employment objective in the perspective of 2020. Differences in assumed employment objectives are remarkable; they reach 21 percentage points from $62.9 \%$ in Croatia to $80 \%$ in Denmark, Holland or Sweden. Thus if we perceive the employment objective assumed for 2020 as the criterion of classification, the EU states can be divided again into 4 groups:

- employment rate below 70\% - Estonia, Ireland, Croatia, Italy, Malta, Romania,

- employment on the level of 70-75\% - Belgium, Spain, Lithuania, Latvia, Poland, Sweden, 
- employment rate on the level of 75-80\% - Bulgaria, Czech Republic, Germany, Greece, France, Cyprus, Hungary, Austria, Portugal, Slovenia and Finland, - employment rate of $80 \%$ - Denmark, Holland and Sweden.

The analysis of direction and dynamics of currently occurring changes and also the gaps that separate individual countries from assumed objective let us state that not all the countries will be able to achieve it. Holland, Sweden and Austria can be found among the countries of high employment rate and good social and economic situation that set themselves an ambitious employment objective and that have the largest chances to achieve it or to be better than that in the perspective of 2020 . Germany and Estonia (countries that already exceeded the determined objective), could have formulated it in a more ambitious way. These are also the countries with relatively low underemployment rate (4-4.5\%). The exception is Estonia, where underemployment is much lower, it does not exceed $1 \%$. The next group includes the countries for which, independently of their current condition, the determined objectives are possible to be achieved. They are Austria, the Czech Republic, Denmark, Finland, France, Lithuania, Latvia, Luxembourg, Ireland and Croatia. There are also high disparities between them: in the Czech Republic underemployment rate is $0.7 \%$, in Denmark, Finland, Lithuania, Latvia, Luxembourg - 2-3\%, but in France and Ireland it is very high $-6-6.7 \%$. In the case of Belgium, France, Malta and Poland the objectives seem to be quite distant and their realisation might require the intensification of activities aimed, among others, at creation of new workplaces. The last group includes Bulgaria, Greece, Hungary, Portugal, Romania, Slovenia, Spain and Cyprus in the case of which these objectives will not be achieved with large probability. If we add high underemployment rates in Spain, Portugal, Greece and Cyprus, the situation is much more difficult.

To improve the situation on the labour market, many Member States have launched reforms, for instance to tackle labour market segmentation (e.g. Spain, Portugal, Italy, France), but the degree of progress varies. Spain simplified contract templates for firms and clarified collective dismissal procedures. Italy relaxed the conditions for companies to use fixed-term and apprenticeship contracts [Draft joint... 2014, p. 24]. Italy adopted two important legislative implementing decrees on employment protection and the revision of unemployment benefits. Recent reforms in France have created only limited scope for employers to depart from branch-level agreements, so another step is reviewing the legal framework governing labour contracts. Poland is another country with limited progress in this area (an act on social security contributions has already been announced, but not implemented yet).

The European Commission pointed out the need for the improvement of the efficiency of public employment services and active labour market policies. The effects of the reforms are seen mainly in Germany, Estonia, Ireland, Greece, Italy, Luxembourg, Spain, Portugal, Slovakia, Finland, Sweden and the United Kingdom. 
On the other hand, in Hungary no progress has been made in revision of the public works scheme and its effectiveness has not improved.

All Member States have progressed in the implementation of Youth Guarantees, but further efforts are required, with special emphasis to vocational education and training. The Commission also highlighted the fact that, contrary to its recommendations, some Member States such as Bulgaria, Italy, Slovakia and Romania have cut public spending for education in recent years [Program for ... 2014, p. 14]. Bulgaria is also one of the countries where limited progress was made on reaching out to non-registered NEETs.

To support job creation, some Member States (e.g, France, Italy, Portugal, Spain) started decentralising their wage setting system and easing the adaptation of wage conditions to the economic environment. The United Kingdom sharpened sanctions for employers who did not apply the requirements of the National Minimum Wage. On the other hand, Bulgaria made no progress on drawing up transparent guidelines for minimum wage setting.

Summarizing, it should be stressed that some positive effects from reforms are visible (for instance in increasing activity rates), but the degree of progress varies across policy areas and between Member States. Resistance to change and the lack of a sense of urgency in some countries contribute to an environment which does not help to create decent jobs. Delays in tackling necessary reforms can increase their ultimate financial, economic and social costs.

\section{Conclusions}

Changes occurring in contemporary labour market, including the necessity to eliminate the consequences of economic crisis, contributed to focussing more attention on the problems observed in the sphere of employment in the European Union. In "Europe 2020" strategy one of the major goals is to reach the 75-percent employment rate in 2020. Activities undertaken in EU mostly aim at the creation of more workplaces which is necessary to slow down the growing tendency with reference to unemployment and underemployment. However, to bring improvement in the living conditions of citizens again, it is necessary to create more productive workplaces in Europe within developing integrated global economy. It is very important, because the consequences of underemployment can significantly influence the financial, personal and social lives of both individuals and their families. However, they can also spill over the employers, economy and the whole society. The number of people who are unemployed and underemployed is rising, so public debate on labour underutilisation should be started as soon as possible. It is necessary to realize that we are dealing with a new crisis of employment.

In the communication of the European Commission [Towards a job-rich... 2012] there were some sectors identified in which the possibility of the occurrence of employment growth seems to be the largest. They are the sector of health benefits, 
information and communication technologies, personal services and services for households, as well as the category of ecological workplaces that are hard to define. The approach based on workplaces adopted in this report provides current data on the subject of employment levels and quality of workplaces both in sectors and professions that observe growth as well as in those that observe the tendency of decline.

It is assessed that to achieve the target value of $75 \%$ employment, around 16 million additionally employed women and men will be necessary [Record on... 2014]. A significant number of young, well educated workers will be ready to start working and the other number of necessary labour resources will be largely recruited among women, elderly people and occupationally inactive people, including migrants. This is a result of demographic conditions. Therefore active policy of labour market together with the strategies of life-long learning and complex integration policy which is emphasised by the European Commission are so important for the attainment of employment objectives. The efficiency of activities that have been undertaken so far remains insufficient and uncertainty related to the assessment of economic situation and development perspectives fundamentally determine the situation in the labour market.

\section{References}

Alternative Measures of Labor Underutilization for States, http://www.bls.gov/lau/stalt.htm (10.10.2014). Bell D.N.F., Blanchflower D.G., 2013, How to Measure Underemployment?, Working Paper Series 137/2013, Peterson Institute for International Economics, pp. 5-11.

Draft joint employment report from the commission and the council accompanying the Communication from the Commission on the Annual Growth Survey 2015, 2014, European Commission, 2014, Brussels, COM(2014) 906 final.

2014 European Semester: Country-specific recommendations. Building Growth, 2014, Communication from the Commission to the European Parliament, the Council, the European Economic and Social Committee and the Committee of the Regions, Brussels, COM(2014) 400 final.

Friedland D.S., Price R.H., 2003, Underemployment: consequences for the health and well-being of workers, American Journal of Community Psychology 32, No. 1, pp. 33-45, retrieved from: www. isr.umich.edu/src/seh/mprc/PDFs/Friedland2003.pdf.

Ham van M., Mulder C.H., Hooimeijer P., 2001, Local underemployment and the discouraged worker effect, Urban Studies, 38, pp. 1733-1751.

http://ec.europa.eu/europe2020/pdf/targets_pl.pdf (14.09.2014).

http://epp.eurostat.ecc.europa.eu/ (12.05.2015).

International Labour Organization (ILO), 1998, Resolution concerning the measurement of underemployment and inadequate employment situations, adopted by the Sixteenth International 2 Economic Approaches to Studying Underemployment 33 Conference of Labour Statisticians, retrieved June 9, 2010, from http://www.ilo.org/global/What_we_do/Statistics/topics/ Underemployment/guidelines.

Orłowski W., Pasternak R., Flaht K., Szubert D., 2010, Procesy inwestycyjne i strategie przedsiębiorstw w czasach kryzysu, Polska Agencja Rozwoju Przedsiębiorczości, Warszawa. 
Program for new skills and jobs: A European contribution towards full employment, 2010, Communication of the Commission to European Parliament, Council, European Economic and Social Commission and Committee of the Regions, Strasbourg, COM(2010)682.

Record on realisation of "Europe 2020" strategy for smart, sustained economic growth favouring social inclusion, 2014, Communication of the Commission to European Parliament, Council, European Economic and Social Commission and Committee of the Regions, Brussels, COM(2014)132.

Skórska A., 2012, Zmiany sytuacji na polskim rynku pracy jako konsekwencja kryzysu gospodarczo-finansowego, Prace Naukowe Uniwersytetu Ekonomicznego we Wrocławiu no 245, ed. J. Sokołowski, M. Rękas, G. Węgrzyn, pp. 443-452.

Strategy for smart and sustained development favouring social inclusion, 2010, Communication of the Committee, Europe 2020, Brussels, COM(2010).

Towards a job-rich recovery, 2012, Communication of European Commission, Brussels, COM(2012).

Wilkins R., 2004, The Extent and Consequences of Underemployment in Australia, Melbourne Institute of Applied Economic and Social Research, The University of Melbourne, Melbourne Institute Working Paper No. 16.

Wilkins R., 2007, The consequences of underemployment for the underemployed, Journal of Industrial Relations No. 49, pp. 247-275. 